\title{
Tuamaka: The Challenge of Difference in Aotearoa New Zealand
}

by Joan Metge. Auckland University Press, Auckland, 2010

xii, 137pp. ISBN 9781869404680

Reviewed by Rachael Fabish

Drawing on metaphors of taura whiri (plaited rope) as the strength created by weaving people together, Tuamaka (a five-strand or six-strand plaited rope) becomes a poetic reference to the six essays presented here as well as their linking theme of nation-building through the binding of peoples. These six essays have all appeared before as conference papers and articles ranging from 1971 to 2008. These six complete - and often overlapping - works have been refined into this small accessible book which will appeal to a wide audience. Metge writes tenderly, evocatively and in plain language.

The publisher's blurb describes this book as 'an engaging manifesto for living together in Aotearoa, turning the challenge of difference into one of our great national assets'. Metge continues her life's work of improving cross-cultural communication. This collection deals perhaps more directly with Pākehā identity-building - through engagement with Māori. As Sir Edward Taihākurei Durie points out in the foreword, 'this is not another study of Māori culture' (p.ix). Metge asks the Pākehā reader to take this material personally.

This is seen explicitly in the first essay, 'Tūrangawaewae: The Trick of Standing Upright Here' (first published 1995). In eight powerful pages, this short essay argues that engagement with Māori is the key to finding a place to stand for non-Māori in Aotearoa New Zealand. For a Pākehā majority unconscious of their cultural inheritance, association with Māori can bring vital self knowledge - 'It often takes the shock of encounter with people who are fundamentally different to reveal us to ourselves' (p.2). Metge also notes that Māori have been standing upright here for centuries. With this comes a 'cultural storehouse' that can enrich us all, including knowledge of the environment, oral and written history, sophisticated literary metaphors and gift-giving practices which emphasise reciprocity. Pākehā failure to understand these things has lead to a plethora of misunderstandings and has prevented the relationship-building promised by the Treaty of Waitangi. While the first essay focuses largely on personal identity, the second 'He Taura Whiri: The Treaty Our Guide' (first delivered 2004) lays out the necessary elements for consciously creating a New Zealand national identity. Metge attempts to reconcile three current models for nationhood - 'We are all New Zealanders', 'biculturalism' and 'multiculturalism' - through 
the 'taura whiri' (plaited rope) metaphor. This recognizes and celebrates diversity, while also strengthening the quality of our shared common life. Metge focuses on four main areas for improvement of this common life: the Treaty of Waitangi, our language, public ceremonial and the creative arts. Rather than focusing on the Treaty as a document, Metge encourages a telling of the story of events surrounding the signing. History is made lively and relevant - 'The whole scene had a contemporary feel to it, an outdoor public event at which today's Kiwis would have felt at home' (p.15). This version has a touch of the mythical about it, an approach no doubt influenced by her interest in Māori storytelling, which she discusses in the next essay, 'Kōrero Pūrākau: Time and the Art of Māori Storytelling'.

Having laid the challenge for Pākehā to learn more from Māori, the following two essays function in this collection as gateways into culture through the treasures of Māori literature. 'Kōrero Pūrākau' (first delivered 1971) demonstrates a commitment to convincing historians that Māori oral history should be taken seriously and without it we are missing half of our national history. Metge argues that Māori myths are grounded in the ancient past, even though they are contemporized - 'myths move with the times, because myths are for telling' (p.40). On the way, by comparing traditional myths recorded in the nineteenth century to those told by modern Māori storytellers, Metge shares with her readers her great enthusiasm for this literary craft.

This same enthusiasm is especially infectious in the next essay 'Whakataukî: Wisdom in Proverbs' (first published 1995), in which Metge invites the reader to follow her into the poetic richness at our doorstep. This chapter looks at several whakataukī, giving translations as well as historical and conceptual details contained within these short metaphorical proverbs. Metge also gives examples of how she has heard these whakataukī used in oratory. She encourages the reader to engage with these treasures in a responsible and uplifting way and includes a review of whakatauki collections available. Furthermore, Metge models this engagement throughout her work, drawing on whakataukī and powerful Māori metaphor in these essays to drive as well as illustrate her arguments. She ends by arguing that these proverbs cannot be fully appreciated in translation. Thus, the essay ultimately works as an enticement to learn the Māori language.

'Huarangatia: Māori Words in New Zealand English' (first delivered 2008) looks at the benefits and challenges of developing 'a true lingua franca' (p.17). Metge examines 23 Māori words that have become part of New Zealand English, charting their history and contemporary use through dictionary references, personal experience and media glosses. She bunches 
these words together around related concepts - for example mana, tapu, utu and aroha - which at times highlight the disparity between how these words are understood in Māori and English. This essay looks at cultural exchange as it is happening in Aotearoa New Zealand. To emphasise the agency on both sides of that exchange, Metge advocates for the use of words such as 'transfer', 'incorporation' and 'transplantation' (rather than 'appropriation') to describe this ongoing process.

The final essay in this collection, 'Anga ā Mua: Living History' (first delivered 2008) takes the reader on the journey Metge has travelled over 50 years of engagement with Māori. Beginning with her field work with urban Māori in Auckland in 1953 and the rural community it led her to, it moves through teaching anthropology and establishing Māori Studies at Victoria University of Wellington, to her studies of myth and literature, her work improving cross-cultural communication and researching whānau, whakamā and Māori teaching, through to Muriwhenua Land Claim submissions. Charting the breakthroughs and limitations, Metge puts her publications in context within periods of personal and national history. Ending with this piece grounds the author's thinking in a real life.

Moreover, demonstrating the grace and humility for which she is renowned, Metge uses this as an opportunity to name and pay respect to all those who have influenced and supported her along the way. 'I made many mistakes, but with the help of generous Māori mentors I survived, learning invaluable lessons' (p.110). Throughout this collection, Metge encourages engagement with Māori culture, while also warning against tokenism and appropriation. To help this, she advocates seeking guidance and permission. Where possible, she seeks partnership with Māori, inspired by the whakataukī 'Ko koe ki tēna, ko au ki tēnei kīwai o te kete' (You at that and me at this handle of the basket). Metge notes that 'association with Māori encourages flexibility of mind' (p.6) and stresses that it is not just the mind 'but heart knowledge of the people who are the holders of that knowledge' (p.8) that is needed. This commitment to people has been reciprocated with staunch support when she has been challenged in her role as a Pākehā academic working with Māori. In this way, she provides a model for emerging researchers. This collection touches on a lot of delicate issues and heated debates and soothes them over with level-headed, informed and compassionate advice that comes from many years of experience. This short book is packed full of gems for non-Māori who want to live with integrity in Aotearoa. Finally, it offers a glimpse at a nationhood formed by the rope of peoples. 